\title{
In vivo Antimalarial Evaluation of Embelin and its Semi-Synthetic Aromatic Amine Derivatives
}

\author{
Kibrnesh Bezu, Daniel Bisrat and Kaleab Asres* \\ Department of Pharmaceutical Chemistry and Pharmacognosy, School of Pharmacy, College of Health Sciences, Addis Ababa University, Addis Ababa, Ethiopia.
}

\begin{abstract}
Background: In less developed countries like Ethiopia, malaria is traditionally treated by remedies prepared from medicinal plants. One such plant that falls in this category is Embelia schimperi Vatke whose fruits are employed for the treatment of a variety of ailments including taeniasis and malaria. Objective: In the present study, the in vivo antimalarial activity of embelin isolated from the fruits of Embelia schimperi Vatke and its semisynthetic aromatic amine derivatives was evaluated. Methods: Silica gel column chromatography was used to isolate embelin from the ethyl acetate extract of the fruits of E. schimperi. Aromatic substituted embelin derivatives were semi-synthesized by using a one-step condensation reaction of embelin with aromatic amines. The compounds were characterized based on their UV, IR, HR-ESIMS, ${ }^{1} \mathrm{H}$ and ${ }^{13} \mathrm{C}$ NMR and DEPT-135 spectral data. Antimalarial activity was evaluated using a modified Peter's 4-day suppressive test against chloroquine sensitive Plasmodium berghei infection in mice. Results: Embelin and the semi-synthetic derivatives showed significant $(p<0.05)$ in vivo antimalarial activity in a dose-dependent manner with $47.8-74.7 \%$ parasite suppression at tested doses of $100-400 \mathrm{mg} / \mathrm{kg}$. Among the compounds semi-synthesized, 5-(p-tolylamino)-2-hydroxy-3-undecylcyclohexa-2,5-diene-1,4-dione showed maximum antimalarial activity ( $74.7 \%$ suppression) at a dose of $400 \mathrm{mg} / \mathrm{kg}$. No major signs of toxicity were observed when either embelin or the semi-synthesized derivatives were administrated to mice at the highest tested dose $(2 \mathrm{~g} / \mathrm{kg})$. Conclusion: The results underline that the antimalarial activity of embelin can be improved by preparing its aromatic semi-synthetic amine derivatives without affecting the safety of the parent molecule.
\end{abstract}

Keywords: Antimalarial, Aromatic substituted embelin, A 4-Day suppressive test, Embelia schimperi, Embelin.

\section{SUMMARY}

- Embelin is the major constituent of the fruits of Embelia schimperi Vatke. with an established antimalarial activity

- It has a long alkyl chain (undecyl) as a substituent, which confers solubility in the non-polar phase and cell permeability.

- Aromatic amine derivatives of embelin were semi-synthesized and one of the compounds obtained by condensation of embelin with p-toludine showed improved antimalarial activity.

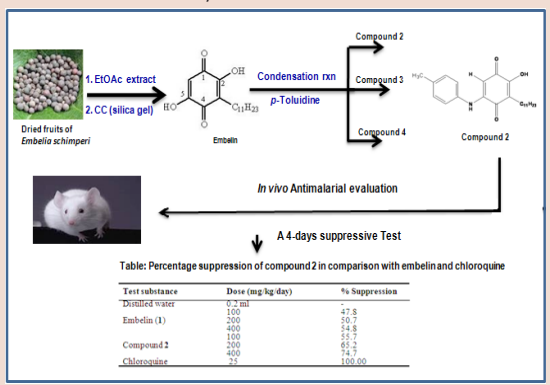

PICTORIAL ABSTRACT

Abbreviations used: LC-MS: Liquid Chromatography-Mass Spectrometry, DEPT: Distortionless Enhancement by Polarization Transfer.

\section{Correspondence:}

Dr. Kaleab Asres PhD, Associate Professor, Department of Pharmaceutical Chemistry and Pharmacognosy, School of Pharmacy, College of Health Sciences, Addis Ababa University, P.O.Box 1176, Addis Ababa Ethiopia.

Email: kasres@gmail.com

DOI : 10.5530/pj.2015.5.10

\section{INTRODUCTION}

Malaria is a parasitic disease caused by Plasmodium species transmitted from the blood of an infected person and passed on to a healthy human by a female Anopheles mosquito. Although the disease was eliminated in most western countries more than 50 years ago, it is still rampant in many African countries with all estimated malaria cases occurring in just five African countries, Ethiopia being one of them. ${ }^{1}$ It is estimated that three-fourths of the land below 2000 meters in Ethiopia is malarious with two-thirds of the country's population at risk. Plasmodium falciparum and $P$. vivax account for $60-70 \%$ and $30-40 \%$ of malaria cases in the country, respectively. ${ }^{2}$ Despite the availability of various malaria control strategies none of them appears to be appropriate and affordable in all contexts. ${ }^{3-4}$ Current treatment for malaria relies on chemotherapy, as no efficient vaccine is available. The burden of this disease is getting worse, mainly due to the increasing resistance of Plasmodium species against the widely available antimalarial drugs. ${ }^{5}$ Although, in recent years artemisinin and its analogues have provided much needed drugs for the treatment of chloroquine-resistant malaria, these are unavailable and/or unaffordable to many people who live in malarious areas. ${ }^{6}$ Effective novel therapeutics are, therefore, needed to combat the parasite.
Srinivas et al. ${ }^{7}$ reported that the methanolic extract of the fruits of Embelia schimperi possesses in vitro activity against chloroquine resistant $P$. falciparum. Embelin (1) is the major constituent of E. ribes. ${ }^{8}$ It has been reported that embelin possesses wide spectrum of biological activities, such as antibacterial, antitumor, anti-inflammatory, antimalarial and analgesic. ${ }^{9-10}$ In the present study embelin (1) isolated from the fruits of E. schimperi and its semi-synthesized aromatic amine derivatives (2-4) have been evaluated for their in vivo antimalarial activity against mice infected with $P$. berghei.

\section{MATERIALS AND METHODS}

\section{General}

Mass spectra (MS) were recorded on a Dionex Ultimate 3000 LC-MS. The measurement was carried out by an electrospray ionization (ESI) method with negative mode. The source voltage and temperature were fixed at $3 \mathrm{kV}$ and $250^{\circ} \mathrm{C}$, respectively. NMR spectra $\left({ }^{1} \mathrm{H},{ }^{13} \mathrm{C}\right.$, DEPT-135) were recorded on a Bruker Avance DMX 400 FT-NMR spectrometer operating at $400 \mathrm{MHz}$ for ${ }^{1} \mathrm{H}$ and $100 \mathrm{MHz}$ for ${ }^{13} \mathrm{C}$ at room temperature 
using deuterated chloroform. A region from 0 to $12 \mathrm{ppm}$ for ${ }^{1} \mathrm{H}$ and 0 to $205 \mathrm{ppm}$ for ${ }^{13} \mathrm{C}$ was employed for scanning. Signals were referred to an internal standard tetra methylsilane (TMS). Chemical shifts are reported in $\delta$ units. Multiplicities of ${ }^{1} \mathrm{H}$ NMR signals are indicated as $s$ (singlet), brs (broad singlet), $d$ (doublet), $t$ (triplet), $m$ (multiplet) and $n r$ (not well resolved). $\mathrm{CHCl}_{3}$ (E. Merck, Stockholm), EtOAc (Research-Lab-Fine, India); $\mathrm{MeOH}$ (Reagent Chemical Ltd, UK); silica gel G6 $\mathrm{F}_{254}$ (E. Merck, Darmstadt), aniline. $o$-toluidine, and $p$-toluidine (Sigma-Aldrich Labor chemikalien GmbH, Germany), acetic acid glacial (Supreme Enterprises, India) have all been used as received.

\section{Experimental animals and test organisms}

Swiss albino mice of either sex weighing 20-30 g and age 6-8 weeks were obtained from the Department of Biology (DoB), College of Natural Sciences (CoNS), AAU animal house. All animals were housed in an airconditioned room and were allowed to acclimatize for one week before the study. The animals were kept at room temperature and were exposed to a $12 \mathrm{~h} \mathrm{light/dark} \mathrm{cycle.} \mathrm{All} \mathrm{the} \mathrm{experiments} \mathrm{were} \mathrm{conducted} \mathrm{in} \mathrm{accor-}$ dance with the internationally accepted laboratory animal use, care and guideline. ${ }^{11}$ Before and during the experiment, the mice were allowed free access to standard pellets and water ad libitum. P. berghei ANKA strain (chloroquine sensitive), was obtained from the DoB, CoNS, AAU. The parasite was subsequently maintained in the laboratory by serial blood passage from mouse to mouse on weekly bases. Chloroquine phosphate (EPHARM, Ethiopia) was used as a reference antimalarial drug.

\section{Plant material}

Fruits of E. schimperi were purchased from local market in March 2012 in Addis Ababa, Ethiopia and authenticated by Mr. Melaku Wondafrash, the National Herbarium, Addis Ababa University (AAU).

\section{Extraction and Isolation of embelin}

Dried and powdered fruits of E. schimperi $(0.5 \mathrm{~kg})$ were macerated in EtOAc at room temp for $72 \mathrm{~h}$, filtered and the solvent evaporated to afford a dark brown solid ( $25 \mathrm{~g}$ ). The crude extract was subjected to silica gel column chromatography and eluted with hexane and EtOAc gradients. Embelin (1) was isolated from the $n$-hexane/EtOAc fraction $(1: 10 \mathrm{v} / \mathrm{v})$.

\section{Preparation of 5-(p-tolylamino)-2-hydroxy-3-undecylcyclohexa-2,5-} diene-1,4-dione (2)

A mixture of embelin (1) $(1 \mathrm{mmol})$ and $p$-toluidine (5) $(1 \mathrm{mmol})$ was dissolved in glacial acetic acid $(30 \mathrm{ml})$ and refluxed on a water-bath for $4 \mathrm{~h}$ as shown in Figure 1. The reaction mixture was cooled to room temperature and poured into ice-cooled diluted $\mathrm{HCl}$. The solid separated was filtered, washed with ethanol, dried and purified by re-crystallization from chloroform/ethanol mixture (4:1) to yield a deep violet prism (2).

Preparation of 5-(o-tolylamino)-2-hydroxy-3-undecylcyclohexa-2, 5-diene-1,4-dione (3)

$o$-Toluidine (6) $(1 \mathrm{mmol})$ was mixed with embelin $(\mathbf{1})(1 \mathrm{mmol})$ in the presence of glacial acetic acid $(40 \mathrm{ml})$ and refluxed for $4 \mathrm{~h}$ on a waterbath. After cooling, the reaction mixture was poured into ice-cooled diluted $\mathrm{HCl}$ to obtain a solid product. It was then filtered, dried and purified by re-crystallization from chloroform/ethanol (4:1) to yield a reddish brown prism (3).

Preparation of 5-(phenylamino)-2-hydroxy-3-undecylcyclohexa-2,5diene-1,4-dione (4)

Embelin (1) (1 mmol), aniline (7) (1 mmol) and glacial acetic acid (40 ml) were mixed and refluxed for $4 \mathrm{~h}$ on a water-bath. After cooling, the reaction mixture was poured into ice-cooled diluted $\mathrm{HCl}$ and the precipitate collected. The product was filtered, dried, and purified by recrystallization from chloroform/ ethanol (2:1) to yield a violet amorphous compound 4 .

\section{Acute toxicity test}

Acute toxicity study was conducted as per the internationally accepted protocol drawn under OECD Guideline $425 .^{12}$ Twenty healthy Swiss female albino mice weighing 23-25 g were randomly divided into 4 groups (Groups A-D) of 5 mice per group. After fasting for 3-4 h, on day one, four mice (one mouse from each group) were given $2 \mathrm{~g} / \mathrm{kg}$ of compounds 1-4, respectively. The mice were then kept under strict observation for physical or behavioral changes for $24 \mathrm{~h}$, with special attention during the first $4 \mathrm{~h}$. Following the results from each of the mice, other four mice were recruited per group and fasted for $3-4 \mathrm{~h}$ and administered a single dose of $2 \mathrm{~g} / \mathrm{kg}$ of each of the test compounds and were observed in the same manner. These observations continued for further 14 days for any signs of overt toxicity such as hair erection, lacrimation and mortality.

\section{In vivo antimalarial activity}

\section{Parasite inoculation}

P. berghei infected albino mice with parasitaemia level of $20-30 \%$ were used as donor. Parasitized erythrocytes were obtained from a donor infected mouse by cardiac puncture with a sterile needle and syringe. The blood was then diluted with physiological saline in such a way that $1 \mathrm{ml}$ blood contains $5 \times 10^{7}$ infected erythrocytes. Sufficient male Swiss albino mice were selected and each inoculated intra peritonealy with $0.2 \mathrm{ml}$ of the infected blood.

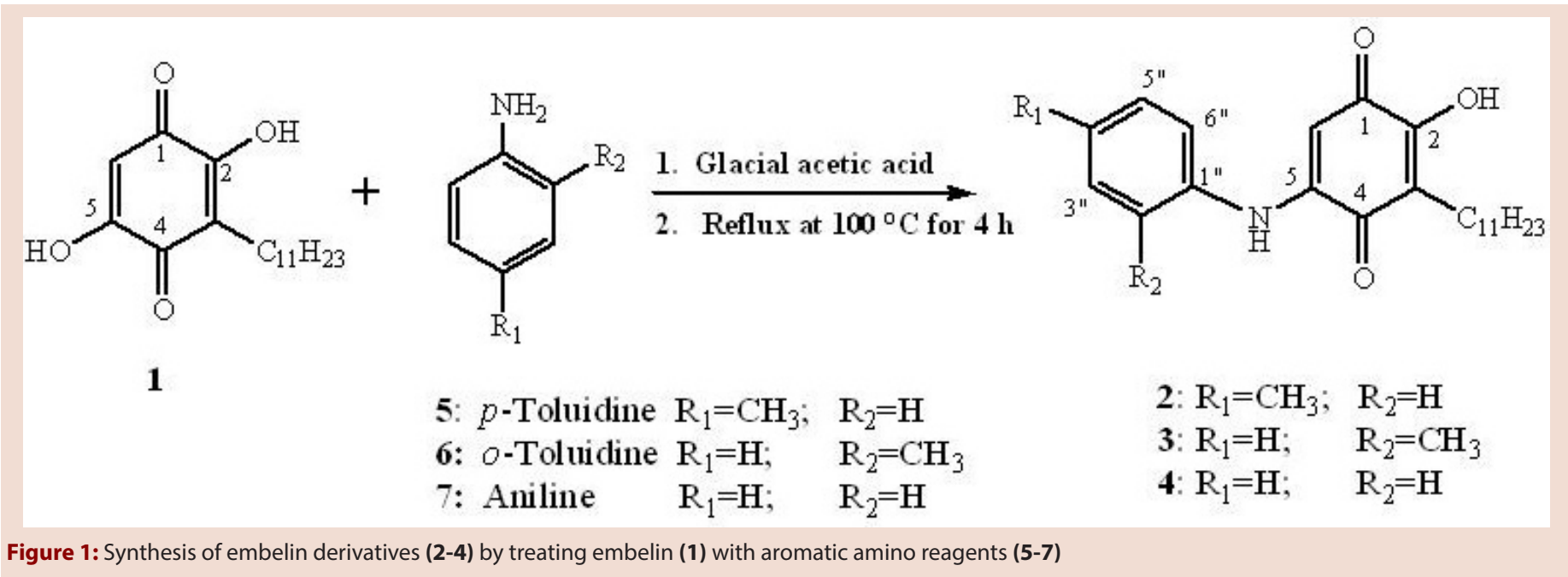




\section{4-Day suppressive test}

A modified Peter's 4-day suppressive test against chloroquine sensitive $P$. berghei infection in mice was employed. The mice were divided into fourteen groups (five mice per group). Group I: negative control, Groups IIa, IIb IIc, IIIa IIIb IIIc IVa IVb IVc and Va Vb Vc, receiving embelin (1) and its derivatives $2-4$ at doses of 100,200 , and $400 \mathrm{mg} / \mathrm{kg} /$ of body weight per day, respectively, while group VI (positive control) were treated with chloroquine at a dose of $25 \mathrm{mg} / \mathrm{kg} / \mathrm{day}$ in a volume of 0.5 $\mathrm{ml}$. All the test substances were administered through oral route by using oral gavages. Treatment was started $3 \mathrm{~h}$ after infection on day 0 and then continued daily for four days (i.e. from day 0 to day 3 ). On the fifth day $\left(\mathrm{D}_{4}\right)$ thin blood smears were prepared fixed in $\mathrm{MeOH}$ and stained with $10 \%$ Geimsa solution to be examined under the microscope with an oil immersion objective of 100x magnification power to evaluate percent suppression. ${ }^{13-14}$

Percentage growth inhibition of the parasites was calculated by the following formula:

Growthinhibition $(\%)=\frac{\text { Parasitaemia in negative cortrol } \cdot \text { Parasitaemia in study group }}{\text { Parasitaemia in negativecontrol }} \times 100$

\section{Monitoring of body weight and mean survival time}

Body weight of each mouse was measured before infection (day 0 ) and on day 4 on healthy mice at the tested doses using digital weighing balance. Mean survival time was recorded from day 1-28 after infection.

\section{Data Analysis}

Results of the study were expressed as mean \pm standard error of mean $(\mathrm{M} \pm \mathrm{SEM})$. Data were analyzed using Windows SPSS Version 20. Comparison of parasitaemia among groups and statistical significance was determined by one-way ANOVA and student t-test at a $95 \%$ confidence interval $(\alpha=0.05)$. The results were considered significant when $P<0.05$.

\section{RESULTS AND DISCUSSION}

\section{Structure elucidation}

Compound (1) was isolated as a bright orange crystal from $n$-hexane/ ethyl acetate $(1: 10 ; \mathrm{v} / \mathrm{v})$. The negative-mode HR-ESI mass spectrum of compound 1 gave a pseudomeolecular ion at $m / z=293.17527\left([\mathrm{M}-\mathrm{H}]^{-}\right)$, indicating a molecular formula of $\mathrm{C}_{17} \mathrm{H}_{26} \mathrm{O}_{4}$ (calcd. $293.175285[\mathrm{M}-\mathrm{H}]^{-}$). ${ }^{1} \mathrm{H}$ NMR spectrum of compound 1 showed a singlet at $6.03 \mathrm{ppm}$, which was assignable to $\mathrm{H}-6$. In addition, a triplet at $0.90 \mathrm{ppm}\left(3 \mathrm{H}, \mathrm{H}-11^{\prime}\right)$, a broad singlet at $1.21 \mathrm{ppm}\left(14 \mathrm{H}, \mathrm{H}-4^{\prime}\right.$ to $\left.\mathrm{H}-10^{\prime}\right)$, a broad singlet at 1.31 $\left(2 \mathrm{H}, \mathrm{H}-3^{\prime}\right)$, a multi plet at $1.51\left(2 \mathrm{H}, \mathrm{H}-2^{\prime}\right)$ and a broad singlet at $2.46 \mathrm{ppm}$ $\left(2 \mathrm{H}, \mathrm{H}-1^{\prime}\right)$ showed the presence of the undecyl chain as part of the structure of compound $\mathbf{1}$. The ${ }^{13} \mathrm{C}$ NMR spectrum of compound $\mathbf{1}$ revealed signals corresponding to 13 carbon atoms only, which does not fit with the number of carbons proposed in the molecular formula above. This is because oxygen bearing ring carbons of 2, 5-dihydroxy-3-alkyl-1,4-benzoquinones do not appear in the ${ }^{13} \mathrm{C}$ NMR spectrum because of fluxional effect caused by intra-molecular hydrogen bonding. This effect leads to long spin relaxation time which in turn leads to the saturation of oxygen-carbon signals as it was also indicated by Mahendran et al. ${ }^{15}$ Hence, compound $\mathbf{1}$ was unequivocally identified as the known compound embelin (1) by comparing its ${ }^{1} \mathrm{H}$ and ${ }^{13} \mathrm{C}$ NMR data (listed below) with those reported in literature for the same compound. ${ }^{10,15}$

\section{Embelin (1)}

A bright orange crystal (hexane/EtOAc; $1: 10$ ); mp: $140-142^{\circ} \mathrm{C}$; Rf: 0.3 (n-propanol/n-BuOH:NH${ }_{4} \mathrm{OH} ; 7: 1: 1$ ); HR-ESIMS (-ve): $m / z=293.17527$ ([M-H] $]^{-}$(calcd. 293.17529 for $\left.\mathrm{C}_{17} \mathrm{H}_{26} \mathrm{O}_{4}\right) ;{ }^{1} \mathrm{H} \mathrm{NMR}\left(\mathrm{CDCl}_{3}, 400 \mathrm{MHz}\right)$ $\delta: 7.28(s, \mathrm{OH}), 6.03(1 \mathrm{H}, s, \mathrm{H}-6), 2.46\left(2 \mathrm{H}, t, \mathrm{H}-1^{\prime}\right), 1.51\left(2 \mathrm{H}, m, \mathrm{H}-2^{\prime}\right)$, $1.31\left(2 \mathrm{H}\right.$, brs, $\left.\mathrm{H}-3^{\prime}\right), 1.21\left(14 \mathrm{H}\right.$, brs, $\left.\mathrm{H}-4^{\prime} / \mathrm{H}-10^{\prime}\right), 0.90\left(3 \mathrm{H}, t, \mathrm{H}-11^{\prime}\right) ;{ }^{13} \mathrm{C}$
NMR ( $\left.\mathrm{CDCl}_{3}, 100 \mathrm{MHz}\right) \delta: 117.0$ (C-3), 102.2 (C-6), C-1, C-2, C-4, C-5 (signals not observed)), 32.0 (C-1'), $29.7\left(\mathrm{C}-2^{\prime}\right), 29.7$ (C-3'), $29.6\left(\mathrm{C}-4^{\prime}\right)$, $29.6\left(\mathrm{C}-5^{\prime}\right), 29.5\left(\mathrm{C}-6^{\prime}\right), 29.4\left(\mathrm{C}-7^{\prime}\right), 28.0\left(\mathrm{C}-8^{\prime}\right), 22.7\left(\mathrm{C}-9^{\prime}\right), 22.6\left(\mathrm{C}-10^{\prime}\right)$, $14.2\left(\mathrm{C}-11^{\prime}\right)$.

In an attempt to improve the antimalarial activity of embelin (1), its aromatic amino derivatives (2-4) were semi-synthesized (Scheme 1) by using a one-step condensation reaction of embelin (1) with $p$-toluidine (5), $o$-toluidine (6) and aniline (7), respectively, and tested against mice infected with $P$. berghei parasites. Condensation reaction of the benzoquinone embelin (1) with aromatic amines (5-7) involves three stage processes: in the first stage the more nucleophilic amino group of the reagents attacks the carbonyl carbon of embelin (1), followed by dehydration and ketoenol tautomersim which would lead to the formation of the target products. ${ }^{16}$ Our assumption was that the more basic derivatives of embelin could improve antimalarial activity by facilitating localization and accumulation of the compounds within the acidic plasmodial vacuole where they undergo protonation and possibly inhibit GSH dependent heme degradation.

Compound $\mathbf{2}$ was obtained as deep violet prisms when embelin (1) was heated with $p$-toluidine (5) in the presence of glacial acetic acid. The negative-mode HR-ESI mass spectrum of compound 2 gave a pseudomeolecular ion at $m / z=382.23983\left([\mathrm{M}-\mathrm{H}]^{-}\right)$, corresponding to a molecular formula of $\mathrm{C}_{24} \mathrm{H}_{33} \mathrm{NO}_{3}$ (calcd. $m / z=382.238219[\mathrm{M}-\mathrm{H}]^{-}$). The ${ }^{1} \mathrm{H}$ NMR spectrum of compound 2 exhibited two sets of ortho-coupling doublets that resonated at $\delta 7.14$ and $7.23 \mathrm{ppm}(J=8.4 \mathrm{~Hz})$, corresponding to p-tolyl-H2",6" and p-tolyl-H3",5", respectively, in addition to signals comparable to those of embelin (1). The presence of 24 carbon atoms in compound 2 was evident from in the ${ }^{13} \mathrm{C}$ NMR spectrum. It was also noted that compound 2 contains 1,4 para-disubstitued benzene ring in the ${ }^{13} \mathrm{C}$ NMR spectrum [ $\delta 122.85$ (C-2",6"), 130.27 (C-3",5"), 134.23 $\left(\mathrm{C}-4^{\prime \prime}\right)$ and $\left.136.42\left(\mathrm{C}-1^{\prime \prime}\right)\right]$. Both ${ }^{1} \mathrm{H}$ and ${ }^{13} \mathrm{C}$ NMR data indicated that the reaction took place at $\mathrm{C}-5$ position, not at the $\mathrm{C}-2$ position of embelin (1) and this might be due to steric factor that is apparent in the latter. Further confirmation of the reaction site was obtained from ${ }^{13} \mathrm{C}$ NMR data, where +8.06 ppm upfield shift of C-6 in 2 ( $\delta$ 94.15) was observed compared to that of the same carbon in $\mathbf{1}(\delta 102.21)$ due to high electron donating nature of the amine group. Thus, compound 2 was finally characterized as 5-( $p$-tolylamino)-2-hydroxy-3-undecyl-cyclohexa-2,5diene-1,4-dione as indicated below.

5-(p-Tolylamino)-2-hydroxy-3-undecylcyclohexa-2,5-diene-1,4-dione (2) A deep violet prism $\left(\mathrm{CHCl}_{3} / \mathrm{EtOH} ; 4: 1\right)$; Yield: $98.3 \%$ (w/w); Mp: 150$151^{\circ} \mathrm{C}$; Rf: $0.48\left(\mathrm{CHCl}_{3} /\right.$ pet ether; $\left.1: 1\right)$; HR-ESIMS (-ve): $m / z=382.23983$ $\left([\mathrm{M}-\mathrm{H}]^{-}\right)$(calcd. 382.23822 for $\left.\mathrm{C}_{24} \mathrm{H}_{33} \mathrm{NO}_{3}\right) ;{ }^{1} \mathrm{H} \mathrm{NMR}\left(\mathrm{CDCl}_{3}, 400 \mathrm{MHz}\right)$ $\delta: 5.96(1 \mathrm{H}, s, \mathrm{H}-6), 2.47$ (2H, $\left.t, \mathrm{H}-1^{\prime}\right), 1.19-2.11\left(18 \mathrm{H}, \mathrm{H}-2^{\prime}-\mathrm{H}-10^{\prime}\right), 0.89$ $\left(3 \mathrm{H}, t, \mathrm{H}-11^{\prime}\right), 7.14\left(2 \mathrm{H}, d, \mathrm{H}-2^{\prime \prime} / \mathrm{H}-6^{\prime \prime}\right), 7.23\left(2 \mathrm{H}, d, \mathrm{H}-3^{\prime \prime} / \mathrm{H}-5^{\prime \prime}\right), 2.37$ $\left(3 \mathrm{H}, s, 4^{\prime \prime}-\mathrm{CH}_{3}\right), 7.28(1 \mathrm{H}$, brs, $\mathrm{NH}) ;{ }^{13} \mathrm{C} \mathrm{NMR}\left(\mathrm{CDCl}_{3}, 100 \mathrm{MHz}\right) \delta$ : 183.0 (C-1), 154.8 (C-2), 116.4 (C-3), 180.3 (C-4), 146.4 (C-5), 94.2 (C6), 32.0 (C-1'), 20.8-29.7 (C-2'-C-10'), 14.2 (C-11'), $136.4\left(\mathrm{C}-1^{\prime \prime}\right), 122.9$ (C-2"/C-6"), 130.3 (C-3"/C-5"), $134.2\left(\mathrm{C}-4^{\prime \prime}\right), 24.3\left(4^{\prime \prime}-\mathrm{CH}_{3}\right)$.

Compound 3, obtained as violet prisms (98.5\% yield), showed a [M-H] at $m / z=382.23857$ in the negative-mode HR-ESI mass spectrum suggesting a molecular formula of $\mathrm{C}_{24} \mathrm{H}_{33} \mathrm{NO}_{3}$ (calcd. $\left.m / z=382.238219[\mathrm{M}-\mathrm{H}]^{-}\right)$. The ${ }^{13} \mathrm{C}$ NMR and DEPT-135 spectra of compound 3 showed signals for 24 different carbon atoms corresponding to 10 methylenes, 5 methines, 2 methyls and 7 quaternary carbon atoms including two carbonyls ( $\delta$ 180.06 and $\delta 183.01)$. Further evidence was obtained from the ${ }^{1} \mathrm{H}$ NMR spectrum, which showed signals consistent with the structure proposed for compound 3: an olefinic proton $\mathrm{H}-6(\delta 5.62, s)$, two methyl groups ( $\delta$ $0.87, t$ and $\delta 2.29, s)$ and four aromatic protons $\mathrm{H}-3^{\prime \prime}-\mathrm{H}-6^{\prime \prime}(\delta 7.25-7.32)$. The remaining assignments are shown below). From the data presented above, the structure of compound $\mathbf{3}$ was deduced as 5-(o-tolylamino)- 


\begin{tabular}{cccc}
$\begin{array}{c}\text { Table 1: Percentage suppression of Plasmodium berghei in mice after four days of } \\
\text { treatment with embelin (1) and its semi-synthetic aromatic amine derivatives (2-4) }\end{array}$ \\
\hline Test substance & Dose (mg/kg /day) & $\begin{array}{c}\text { \% Parasitaemia } \pm \\
\text { SEM }\end{array}$ & \% Suppression \\
\hline Distilled water & $0.2 \mathrm{ml}$ & $47.12 \pm 3.21$ & - \\
Embelin (1) & 200 & $23.22 \pm 2.64^{* \mathrm{~b}}$ & 50.7 \\
& 400 & $21.32 \pm 3.82^{* \mathrm{c}}$ & 54.8 \\
Distilled water & 100 & $24.60 \pm 1.73^{* \mathrm{a}}$ & 47.8 \\
& $0.2 \mathrm{ml}$ & $51.53 \pm 8.32$ & - \\
Compound 2 & 100 & $22.84 \pm 1.49^{* \mathrm{~d}}$ & 55.7 \\
& 200 & $17.92 \pm 5.46^{* \mathrm{e}}$ & 65.2 \\
Distilled water & 400 & $13.06 \pm 3.19^{* \mathrm{f}}$ & 74.7 \\
& $0.2 \mathrm{ml}$ & $51.53 \pm 8.32$ & - \\
Compound 3 & 100 & $26.20 \pm 2.79^{* \mathrm{a}}$ & 49.2 \\
& 200 & $25.16 \pm 2.44^{* \mathrm{~b}}$ & 51.2 \\
Distilled water & 400 & $22.31 \pm 4.98^{* \mathrm{c}}$ & 56.7 \\
& $0.2 \mathrm{ml}$ & $51.53 \pm 8.32$ & - \\
Compound 4 & 100 & $24.00 \pm 1.87^{* \mathrm{~g}}$ & 53.4 \\
Chloroquine & 200 & $23.80 \pm 1.78^{* \mathrm{~h}}$ & 53.8 \\
\hline
\end{tabular}

Values are presented as $\mathrm{M} \pm \mathrm{SEM} ; \mathrm{n}=5 ; \mathrm{p}<0.001$ compared to the negative control; values with different letters are significantly different $(\mathrm{p}<0.05)$.

2-hydroxy-3-undecylcyclohexa-2,5-diene-1,4-dione.

5-(o-Tolylamino)-2-hydroxy-3-undecylcyclohexa-2,5-diene-1,4-dione (3) A violet prism $\left(\mathrm{CHCl}_{3} / \mathrm{EtOH} ; 4: 1\right)$; Yield: $98.5 \%$ (w/w); Mp: $120-121^{\circ} \mathrm{C}$; $\mathrm{Rf}=0.49\left(\mathrm{CHCl}_{3} /\right.$ pet ether; 1:1); HR-ESIMS (-ve): $\mathrm{m} / z=382.23857$ ([M$\left.\mathrm{H}]^{-}\right)$(calcd. 382.23822 for $\left.\mathrm{C}_{24} \mathrm{H}_{33} \mathrm{NO}_{3}\right) ;{ }^{1} \mathrm{H} \mathrm{NMR}\left(\mathrm{CDCl}_{3}, 400 \mathrm{MHz}\right) \delta$ : $5.62(1 \mathrm{H}, s, \mathrm{H}-6), 2.47\left(2 \mathrm{H}, t, \mathrm{H}-1^{\prime}\right), 1.12-2.20\left(18 \mathrm{H}, m, \mathrm{H}-2^{\prime}-\mathrm{H}-10^{\prime}\right)$, $0.87\left(3 \mathrm{H}, t, \mathrm{H}-11^{\prime}\right), 7.25-7.32\left(4 \mathrm{H}, n r, \mathrm{H}-3^{\prime \prime}-\mathrm{H}-6^{\prime \prime}\right), 2.29\left(3 \mathrm{H}, s, 2^{\prime \prime}-\mathrm{CH}_{3}\right)$, $7.81(1 \mathrm{H}$, brs, $\mathrm{NH}) ;{ }^{13} \mathrm{C} \mathrm{NMR}\left(\mathrm{CDCl}_{3}, 100 \mathrm{MHz}\right) \delta: 183.0(\mathrm{C}-1), 154.6$ (C-2), 116.2 (C-3), 180.1 (C-4), 147.1 (C-5), 94.1 (C-6), 32.0 (C-1'), 17.8$29.7\left(\mathrm{C}-2^{\prime}-\mathrm{C}-10^{\prime}\right), 14.2\left(\mathrm{C}-11^{\prime}\right), 135.0\left(\mathrm{C}-1^{\prime \prime}\right), 133.1\left(\mathrm{C}-2^{\prime \prime}\right), 127.3\left(\mathrm{C}-3^{\prime \prime}\right)$, $127.1\left(\mathrm{C}-4^{\prime \prime}\right), 131.5\left(\mathrm{C}-5^{\prime \prime}\right), 124.5\left(\mathrm{C}-6^{\prime \prime}\right), 17.8\left(2^{\prime \prime}-\mathrm{CH}_{3}\right)$.

Compound 4, a reddish brown prism, was obtained by reaction of embelin (1) with aniline (7) in the presence of glacier acetic acid. A close analysis showed characteristic signals for a substituted 1,4-benzoquinone moiety in the ${ }^{1} \mathrm{H}$ NMR $(\delta 6.03, s, \mathrm{H}-6)$ and ${ }^{13} \mathrm{C}$ NMR $(\delta$ 94.48, C-6; $\delta 182.93, \mathrm{C}-1 ; \delta 180.37, \mathrm{C}-4)$ spectra.

The molecular formula of compound 4 was deduced as $\mathrm{C}_{23} \mathrm{H}_{31} \mathrm{NO}_{3}$ by HR mass spectrometry (observed: $m / z=368.22259$ ([M-H]; calcd. $m /$ $z=368.222569$ ). The ${ }^{13} \mathrm{C}$ NMR, along with the DEPT spectra, revealed the presence of one $\mathrm{CH}_{3}$, ten $\mathrm{CH}_{2}$, six $\mathrm{CH}$ and six quaternary carbons, including two carbonyl carbons. The complete assignments of ${ }^{1} \mathrm{H}$ and ${ }^{13} \mathrm{C}$ NMR data are summarized below. Thus, the structure of compound 4 was elucidated as 5-(phenylamino)-2-hydroxy-3-undecylcyclohexa-2,5diene-1,4-dione.

5-(Phenylamino)-2-hydroxy-3-undecylcyclohexa-2,5-diene-1,4-dione (4) A reddish brown prism $\left(\mathrm{CHCl}_{3} / \mathrm{EtOH} ; 2: 1\right)$; Yield: $96.1 \%$ (w/w); Mp: $157-$ $159^{\circ} \mathrm{C}$; Rf: $0.53\left(\mathrm{CHCl}_{3} /\right.$ pet ether; $\left.1: 1\right)$; HR-ESIMS (-ve): $m / z=368.22259$ $\left([\mathrm{M}-\mathrm{H}]^{-}\right)$(calcd. 368.22257 for $\left.\mathrm{C}_{23} \mathrm{H}_{31} \mathrm{NO}_{3}\right){ }_{1}^{1} \mathrm{H} \mathrm{NMR}\left(\mathrm{CDCl}_{3}, 400 \mathrm{MHz}\right)$ $\delta$ : $6.03(1 \mathrm{H}, s, \mathrm{H}-6), 2.47$ (2H, $\left.t, \mathrm{H}-1^{\prime}\right), 1.12-2.21\left(18 \mathrm{H}, m, \mathrm{H}-2^{\prime}-\mathrm{H}-10^{\prime}\right)$, $0.89\left(3 \mathrm{H}, t, \mathrm{H}-11^{\prime}\right), 7.27\left(2 \mathrm{H}, n r, \mathrm{H}-2^{\prime \prime} / \mathrm{H}-6^{\prime \prime}\right), 7.42\left(2 \mathrm{H}, t, \mathrm{H}-3^{\prime \prime} / \mathrm{H}-5^{\prime \prime}\right)$, $7.28\left(1 \mathrm{H}, n r, \mathrm{H}-4^{\prime \prime}\right), 7.99(1 \mathrm{H}$, brs, $\mathrm{NH}) ;{ }^{13} \mathrm{C} \mathrm{NMR}\left(\mathrm{CDCl}_{3}, 100 \mathrm{MHz}\right) \delta$ :
182.9 (C-1), 154.3 (C-2), 116.3 (C-3), 180.4 (C-4), 146.0 (C-5), 94.5 (C6), $32.0\left(\mathrm{C}-1^{\prime}\right), 22.7-29.7$ (C-2'-C-10'), $14.2\left(\mathrm{C}-11^{\prime}\right), 136.9$ (C-1') 122.8 (C-2"/C-6"), $129.8\left(\mathrm{C}-3^{\prime \prime} / \mathrm{C}-5^{\prime \prime}\right), 126.3\left(\mathrm{C}-4^{\prime \prime}\right)$.

\section{Acute toxicity study}

Acute toxicity study indicated that embelin and its derivatives caused no mortality up to the highest tested dose of $2 \mathrm{~g} / \mathrm{kg}$ within the first $24 \mathrm{~h}$ as well as for the following 14 days. Also, the compounds did not cause overt toxicity such as lacrimation, tremors, hair erection, salivation, diarrhoea. Thus, the median lethal dose $\left(\mathrm{LD}_{50}\right)$ of all compounds is said to be greater than $2000 \mathrm{mg} / \mathrm{kg}$, indicating a good safety margin.

\section{Antimalarial activity}

In the present study, a 4-day suppressive test indicated that embelin (1) possesses in vivo antimalarial activity against $P$. berghei, with maximum parasitaemia suppression of $54.8 \%$ at a dose of $400 \mathrm{mg} / \mathrm{kg}$. It has been reported that malaria parasite degrades up to $80 \%$ of the haemoglobin in the host cell and releases heme which is toxic to parasite and their host. ${ }^{17}$ Neutralization of heme occurs mainly due to hemozoin formation by the parasites. Inhibition of hemozoin formation is, therefore, an important drug target to kill the parasite cell. ${ }^{18}$ Inhibition of hemozoin formation takes place through different routes via drug binding to the heme or inhibition of glutathione (GSH) dependent heme degradation. According to Huang et al, ${ }^{19}$ embelin acts as an antimalarial with a mechanism of action similar to that of the well-known 4-aminoquinoline chloroquine, by inhibiting hemozoin formation. The presence of hydroxyl groups in chloroquine bind iron of heme and lead to the formation of $\pi-\pi$ adducts, which inhibit hemozoin formation. Similarly, Basilico et al. ${ }^{20}$ proposed that the hydroxyl groups present in embelin may bind to the iron of heme and inhibit the formation of hemozoin which is essential for survival of parasites.

As shown in Table 1, embelin (1) and its derivatives (2-4) have produced a dose dependent chemosuppression, with maximum parasite suppres- 
Table 2: Mean survival time of Plasmodium berghei infected mice after treatment with embelin (1) and its semi-synthetic aromatic amine derivatives (2-4)

\begin{tabular}{ccc}
\hline Test substance & Dose $(\mathrm{mg} / \mathrm{kg} /$ day) & $\begin{array}{c}\text { Mean survival time } \\
\text { (days) }\end{array}$ \\
\hline Distilled water & $0.2 \mathrm{ml}$ & $5.60 \pm 0.55$ \\
& 100 & $7.80 \pm 0.44^{*}$ \\
Embelin (1) & 200 & $8.00 \pm 0.71^{* *}$ \\
& 400 & $9.00 \pm 0.00^{* *}$ \\
Compound 2 & 100 & $7.80 \pm 0.44^{*}$ \\
& 200 & $7.90 \pm 0.54^{*}$ \\
Compound 3 & 400 & $8.00 \pm 0.00^{*}$ \\
& 100 & $7.00 \pm 1.26^{*}$ \\
Compound 4 & 200 & $7.00 \pm 1.00^{*}$ \\
Chloroquine & 400 & $7.40 \pm 0.89^{* *}$ \\
\hline
\end{tabular}

Values are presented as $\mathrm{M} \pm \mathrm{SEM} ; \mathrm{n}=5 ;{ }^{*} \mathrm{p}>0.05 ;{ }^{* *}=\mathrm{p}<0.01 ;{ }^{* * * *}=\mathrm{p}<0.001$ when compared to the negative control; $\mathrm{ND}=$ No death within the follow-up 28-days.

sion of $74.7 \%$ for compound 2 at a dose of $400 \mathrm{mg} / \mathrm{kg} /$ day. The semi-synthesized compounds are more basic than embelin due to the presence of amine substituent which enhances $\mathrm{pKa}$ values. This could be important for accumulation of the compounds in the acidic digestive vacuole of the parasite where they undergo protonation. Whilst the electron-donating ability of the para-substituted methyl group makes compound 2 to be relatively more basic, the ortho-substituted methyl group in compound 3 imparts steric hindrance to protonation of the amine group. Thus, as shown in Table 1, compound $\mathbf{2}$ is the most active while compound $\mathbf{3}$ is the least active among the synthesized compounds, with compound 4 showing intermediate activity due to the presence of the phenyl group which has neither electron-donating nor withdrawing effect. According to $\mathrm{Ru}$ drapal and Cheita, ${ }^{21}$ replacement of $4{ }^{\prime}$-OH group in 4-amino-quinolines by several amino substituent, provides interesting antimalarial activity. 4-Amino-quinolines accumulate at high concentrations into the parasite's acidic food vacuole, which is their site of action. Thus, stronger basicity of a molecule increases antimalarial activity due to better uptake in the vacuole owing to the $\mathrm{pH}$ gradient between the cytosol and the acidic vacuole.

The results of the present study revealed that the antimalarial effect of the semi-synthetic derivatives ( 2 and $\mathbf{4}$ ) is more than that of their parent compound (1), justifying our assumption that it would be possible to enhance activity by preparing the more basic amino derivatives of embelin (1). The antimalarial efficacy of embelin (1) and its derivatives was further evaluated by a mean survival time testing. ${ }^{22}$ The mean survival time of mice treated with embelin (1) and its derivatives was longer when compared with vehicle treated animals. As shown in Table 2, all the tested compounds prolonged mean survival time of the experimental animals in a dose dependent manner.

The mean weight of each group, with the exception of the vehicle and compound 3 ( $200 \mathrm{mg} / \mathrm{kg} /$ day) treated groups, declined on the fifth day of infection (Table 3). The observed decline in weight might be explained by the direct effect of the compounds to cause appetite loss of the experimental animals.

\section{CONCLUSION}

In conclusion, the results of the present study underline that the antimalarial activity of embelin can be improved by preparing its aromatic semi-synthetic amine derivatives without affecting the safety of the parent molecule.

\section{ACKNOWLEDGMENTS}

The authors would like to acknowledge the International Science Programme, Uppsala University, Sweden, for partly funding (Project Number ETH002) this work.

Table 3: Body weight of Plasmodium berghei infected mice after the administration of embelin (1) and its semi-synthetic aromatic amine derivatives (2-4)

\begin{tabular}{ccccc}
\hline Test substances & $\begin{array}{c}\text { Dose }(\mathrm{mg} / \mathrm{kg} / \\
\text { day })\end{array}$ & Wt D $_{0} \pm \mathrm{SEM}$ & ${\text { Wt } \mathrm{D}_{4} \pm \mathrm{SEM}}$ & Percent change \\
\hline \multirow{2}{*}{ Distilled water } & $0.2 \mathrm{ml}$ & $24.34 \pm 0.34$ & $23.04 \pm 1.21$ & -5.6 \\
& 100 & $22.30 \pm 0.70$ & $20.94 \pm 1.57$ & -6.5 \\
Embelin (1) & 200 & $22.94 \pm 0.13$ & $21.46 \pm 1.61$ & -6.9 \\
& 400 & $24.04 \pm 0.20$ & $23.24 \pm 1.75$ & -3.4 \\
Compound 2 & 100 & $23.00 \pm 0.21$ & $21.66 \pm 0.59$ & -6.2 \\
& 200 & $23.20 \pm 0.16$ & $22.52 \pm 1.22$ & -3.0 \\
Compound 3 & 400 & $24.12 \pm 0.15$ & $24.64 \pm 1.07$ & 2.1 \\
& 100 & $22.24 \pm 0.23$ & $21.20 \pm 1.48$ & -4.9 \\
Compound 4 & 200 & $22.28 \pm 0.17$ & $22.62 \pm 1.08$ & 1.5 \\
Chloroquine & 400 & $22.56 \pm 0.13$ & $20.98 \pm 1.16$ & -7.5 \\
\hline
\end{tabular}

Values are presented as $\mathrm{M} \pm \mathrm{SEM} ; \mathrm{n}=5$; $\mathrm{Wt} \mathrm{D}_{0}$ : weight pre-treatment on day zero; $\mathrm{Wt} \mathrm{D}_{4}$ : weight posttreatment on day five. 


\section{CONFLICT OF INTERESTS}

Authors do not have any conflict of interest.

\section{REFERENCES}

1. World Health Organization. World Malaria Report Geneva, Switzerland; 2010.

2. Woyessa A, Deressa W, Ali A, Lindtjørn B. Prevalence of malaria infection in Butajira area, south-central Ethiopia. Malaria J. 2012; 11: 84.

3. Uneke CJ. Impact of placental Plasmodium falciparum malaria on pregnancy and perinatal outcome in sub-Saharan Africa. II: Efects of placental malaria on perinatal outcome; Malaria and HIV. Yale J Biol Med. 2007; 80(3): 95-103.

4. Beroe J, Frederich M, Quetin-Leclercq J. Antimalarial compounds isolated from plants used in traditional medicine. J Pharm Pharmacol. 2009; 61(11): 1401-33.

5. Mehlin C. Structure-based drug design for Plasmodium falciparum. Comb Chem High T Scr. 2005; 8(1): 5-14.

6. Valdés AFC, Martínez JM, Lizama RS, Gaitén YG, Rodríguez DA, Payrol JA. In vitro antimalarial activity and cytotoxicity of some selected Cuban medicinal plants. Rev Inst Med Trop Sao Paulo. 2010; 52(4): 197-201.

7. Srinivas K. Mahesh $C$, Jagadeesh N. Anti-mitotic activity of embelin derivatives, Int J Phytopharmacol. 2010; 1(2): 97-102.

8. Radhakrishnan N, Gnanamani A, Mandal AB. A potential antibacterial agent embelin, a natural benzoquinone extracted from Embelia ribes. Biol Med. 2011; 3(2): 1-7.

9. Mahishi P. Srinivasa BH, Shivanna MB. Medicinal plant wealth of local communities in some villages in Shimoga district of Karnataka, India. J Ethnopharmacol. 2005; 98(3): 307-12.

10. Awino OS, Kiprono PC, Keronei KP, Kaberia F, Obala AA. Antimicrobial activity of 2,5-dihydroxy-3-methyl-1,4-benzoquinone from Embelia schimperi. Z Naturforsch C. 2008; 63(1-2): 47-50
11. Institute of Laboratory Animal Resources: Guide for the Care and Use of Laboratory Animals. $7^{\text {th }}$ edition. Washington DC: National Academy Press; 1996

12. OECD. Guidelines for the testing of chemicals; Acute Oral Toxicity: Up-and down-procedures.: OECD Publishing; 2001. http://www.oecdbookshop.org, No 425, Adopted; December 2001. No 425

13. Dikasso D, Makonnen E, Debella. A, Abebe D, Urga K, Makonnen W, et al. In vivo antimalarial activity of hydroalcoholic extracts from Asparagus africanus Lam. in mice infected with Plasmodium berghei. Ethiop J Health Dev. 2006; 20(2): 112-8.

14. Akuodor GC, Idris-Usman M, Anyalewechi N, Eucheria O, Ugwu, CT, Akpan JL, et al. In vivo antimalarial activity of ethanolic leaf extract of Verbena hastata against Plasmodium berghei in mice. J Herb Med. Toxicol. 2010; 4(2): 17-23.

15. Mahendran S, BadamI S, Ravi S, Thippeswamy BS, Veerapur VP. Synthesis and evaluation of analgesic and anti-inflammatory activities of most active free radical scavenging derivatives of embelin-A structure-activity relationship. Chem Pharm Bull. 2011; 59(8): 913-9.

16. Brahmeshwari G. Synthesis of 6,7-hydroxy-3-aryl-5-undecyl 4,1,2-benzoxadiozines. Indian J Chem B. 2009; 48B(10): 1457-61.

17. Koyama J. Anti-infective quinone derivatives of recent patents. Recent Pat Antiinfect Drug Discov. 2006; 1(1): 113-25

18. Fidock DA, Rosenthal PJ, Croft SL, Brun R, Nwaka S. Antimalarial drug discovery: Efficacy models for compound screening. Nat Rev Drug Discov. 2004; 3(6): $509-20$.

19. Huang CY. Determination of binding stoichiometry by the continuous variation method. The Job plot, Method Enzymol Part C. 1982; 87: 509-25.

20. Basilico N, Monti D, Olliaro P, Taramelli D. Non-iron porphyrins inhibit betahaematin (malaria pigment) polymerisation. FEBS Letters 1997; 409(2): 297-9.

21. Rudrapal M, Chetia D. Novel 4-aminoquinoline analogues as antimalarial agents: A review. Der Pharmacia Lettre 2011; 3(3): 29-36.

22. Krettli AU, Adebayo JO, Krettli LG. Testing of natural products and synthetic molecules aiming at new antimalarials. Curr Drug Targets. 2009; 10(3): 261-70.

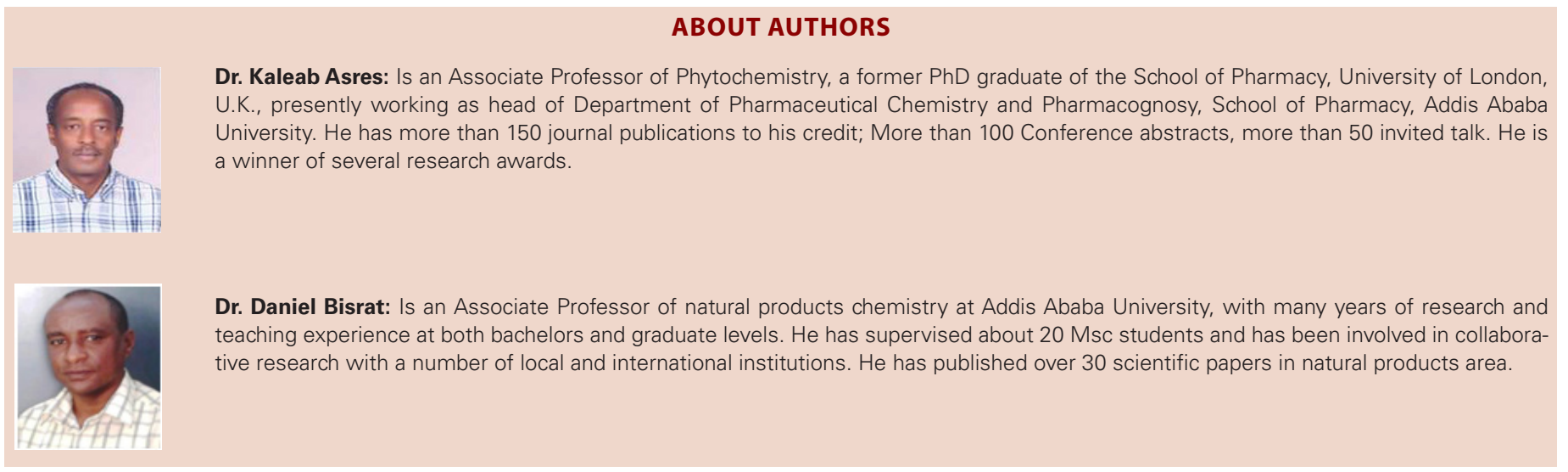

